\title{
Prophetic preaching in the socio-economic and socio-political crisis of Zimbabwe
}

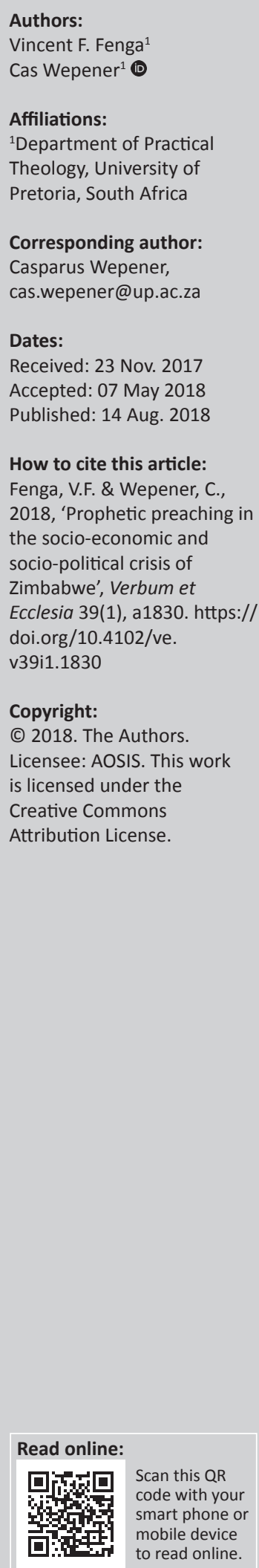

In Zimbabwe, there are different preachers who have great names, but when it comes to prophetic preaching they lag behind as compared to South Africa, which has great preachers in prophetic preaching like Desmond Tutu. In this era, however, we are challenged with a situation of socio-economic and socio-political crisis: the enormous poverty among approximately $95 \%$ of the population. This article discusses the circumstances for prophetic preaching in the contemporary context of Zimbabwe, which are a clear understanding of the poverty position and cohesion of the church with the poor, a good understanding of the image of prophetic preaching as a specific type of preaching that encompasses the four elements of preaching: the preacher, as well as the congregation (hearers), the sermon and the Holy Spirit for prophetic preaching.

Interdisciplinary and intradisciplinary implications: This article discusses the circumstances for prophetic preaching in the context of Zimbabwe, which are a clear understanding of the poverty position and cohesion of the church with the poor. In our analysis of prophetic preaching in Zimbabwe, the emphasis is put on prophecy, healing, deliverance and prosperity. This article argues that prophetic preaching is approaching the biblical text with a view to interpret it as preaching in a context of poverty. It should be done from the perspective of the poor, therefore in terms of their need for justice and righteousness.

\section{Introduction}

If one were to turn to print or electronic media in Zimbabwe, especially Star FM ${ }^{1}$, one could hardly listen to a radio programme for more than $1 \mathrm{~h}$ without hearing from a prophet advertising his or her services. The main words from these prophets are, 'those who are suffering from any diseases ... those who are looking for jobs ... those who want to get married ...'. People are invited to attend church services or to book one-on-one meetings with these prophets so that they are prayed for to get married, or to get jobs. The frequent advertisements from these prophets clearly indicate that the lives of many Zimbabweans are under realistic threat as they face serious economic challenges. The country has faced a serious challenge today, a situation of unendurable poverty of about $96 \%$ of the general populace, according to Crystal Lombardo, a contributing editor for Vision Launch (www.visionlaunch.com; accessed 24 October 2017). In this article, I discuss the current Zimbabwean context of colossal poverty, dissipated politics and personal amelioration by the exclusive people in our society, which I am convinced challenges preachers today to preach prophetically in our situation. This phenomenon of colossal poverty puts the poor in our country in a situation of injustice and exclusion from the elite of the Zimbabwean population (Pieterse 2013:1). The practice of preaching this inhuman situation creates a problem for the preacher. Should we preach prophetically on the shortcomings of the present social order in such a context (Tisdale 2010:9)?

In discovering this problem, Pieterse (2013) generated two questions that are critical to this article:

- What circumstances challenge a preacher to take a prophetic stance in society?

- What is prophetic preaching? (p1)

In addressing these questions, the book by Pieterse (2004) and Tisdale (2010) draws our consideration again on the need for prophetic preaching. The Zimbabwean socio-economic and socio-political crisis is different from the South African and United States (US) situation. As a result we must address our situation with a particular Zimbabwean method. In responding to the questions raised above, I will explore the situations that qualify prophetic preaching in the socio-economic and socio-political crisis of Zimbabwe. This is the ultimate purpose of this 1.Star FM is a radio station in Zimbabwe owned by Zim Papers, which is the state-owned media organisation. 


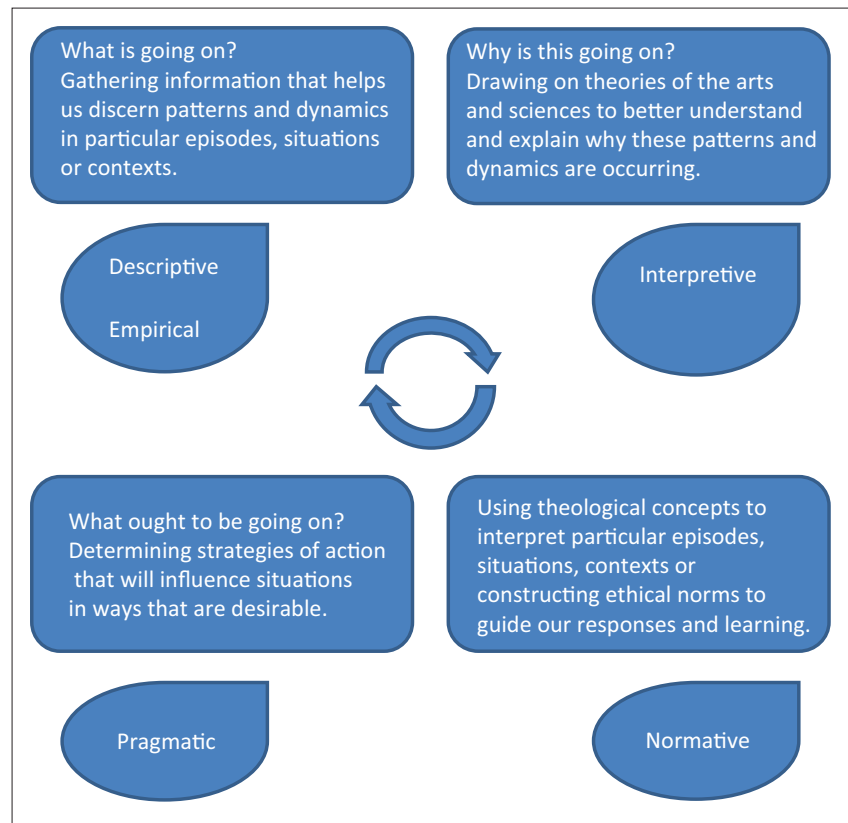

Source: Adapted from Osmer, R.R., 2008, Practical theology: An introduction, William B. Eerdmans, Cambridge, p. 4

FIGURE 1: The core tasks of practical theological interpretation.

article: to describe and critically analyse the circumstances in which prophetic preaching in an unfair and indecorous state of affairs would be necessary. To begin with, a presentday Zimbabwean context of socio-economic and sociopolitical crisis will be described using the theoretical framework by Richard Osmer (2008:4), followed by a description of prophetic preaching and a discussion on the four elements of preaching, which are preacher, congregation, sermon and Holy Spirit. ${ }^{2}$

\section{The political background of Zimbabwe (descriptive-empirical task)}

These four tasks will be used in understanding the socioeconomic and socio-political crisis of Zimbabwe. As a framework of this article, all the tasks will be explored and it is important to note that the episodes may often overlap. The first task is the descriptive-empirical task. Osmer (2008:32) notes that ' $[p]$ ractical theology begins with episodes, situations, or contexts that call for interpretation'. Therefore, practical theology invites students to interpret the texts of contemporary lives and practices called 'living human documents'. The descriptive task seeks to answer the question, what is going on? Osmer grounds the descriptive task in terms of 'a spirituality of presence'. It is a matter of attending to what is going on in the lives of 'individuals, families, and congregations' (Osmer 2008:33-34). It is of great importance to discuss what is going on and why it is going on in Zimbabwe using the descriptive-empirical task. To do so, we will begin by looking at the socio-political background of Zimbabwe.

2.The sources used in this article came from published books, newspapers and other non-published materials because the socio-economic and socio-political issues in Zimbabwe are recorded by many organisations and individuals.
To understand the political background of Zimbabwe, it is important to note that by early 2007, life in Zimbabwe had become a tough and ugly battle for survival for the ordinary people. During the 2008 election the opposition Movement for Democratic Change (MDC) decided to join forces against the ruling party, the Zimbabwe African National Union Patriotic Front (ZANU-PF). The harmonised election, which was held on 29 March 2008, went on well without any violence. MDCTsvangirai (MDC-T) won the election for the first time since independence; ZANU-PF lost their majority in the house of the Assembly, with MDC-T having 99 and ZANU-PF 97 out of the 210, while MDC-Mutambara had 10 (Harare Morning Daily News, 16 April 2008:1). The Zimbabwe Electoral Commission held the presidential results and announced them after 5 weeks. It was later announced that Tsvangirai had won $47.9 \%$, Mugabe $43.2 \%$ and Makoni $8.3 \%$ of the presidential vote (Harare Morning Herald, 03 May 2008:2). As a result of this result no one was declared a winner, because the constitution of Zimbabwe required a 50\% plus one majority. Tsvangirai's percentage was therefore insufficient and a run-off election between Tsvangirai and Mugabe would have to be held; this was scheduled for 27 June.

The Southern African Development Community (SADC) appointed former South African President Thabo Mbeki to mediate the talks between the two MDCs and ZANU-PF; this was after Mugabe and ZANU-PF had engaged in violence during the presidential run-off, which resulted in Tsvangirai withdrawing. After a long period of debates, Mbeki succeeded in uniting the three parties, which saw Zimbabwe entering a new phase of politics by the signing of the Global Political Agreement (GPA) on 15 September 2008. Though the GPA was signed and people pretended to be happy by shaking hands, it was just a marriage of convenience because there was a lot of mistrust by the three parties because of what had happened just before. The crisis in the Government of National Unity (GNU) was witnessed in its infant stages when office bearers were supposed to be sworn into their offices. This was targeted at all people who had caused mayhem to ZANU-PF when they were campaigning in their parties - for instance, Mugabe refused to swear in Roy Bennett as Deputy Minister of Agriculture on an MDC-T ticket (Coltart 2016:478).

The enormous majority of Zimbabweans long for freedom. This longing was demonstrated in the immense vote in approval of the new constitution in 2013, which, although flawed, resulted in a document that marks an important step forward. While by no means perfect, it provides a useful foundation upon which to build. In the pursuit of democracy there is never a final victory because democracy is a process, not an event. Even countries that have had democratic constitutions for over a century experience the evolution, refinement and, on occasion, reversal of democracy. Zimbabwe, as a young emerging democracy, is no different. The struggle continues, yes, it does indeed. Equally important, the new Zimbabwe must be an agency for generational change in politics, as the gateway through which the country and the nation can get transition to the 21st century. 


\section{The socio-economic background}

Zimbabwe experienced an intense economic and political crisis at the end of the 1990s and into early 2000. This period nearly dragged the country to the brink of total collapse. Recent scholarship on the subject was by scholars such as Raftopoulos (2009b), Hammer, MacGregor and Landau (2010), Jones (2010), Musoni (2010) and Chiumbu and Musemwa (2012). This article would agree with Chiumbu and Musemwa, who diverted from the idea that the crisis of Zimbabwe was moored on the ground - that it is basically one-dimensional, if not reductionist, to view and characterise the political situation in Zimbabwe as a mono-crisis. Such a viewpoint simply does not permit sufficient perspective to get at the diverse everyday experiences arising out of the different and immediate fundamental crises created by the political turmoil in Zimbabwe roughly between 1998 and 2009.

The political conflict left in its wake various other crises, the majority of which were crises associated with resource scarcities, namely a water crisis, health crisis, monetary or cash crisis, fuel crisis, energy and electricity crisis, food crisis and cholera crisis (Chiumbu \& Musemwa 2012:10). Chiumbu and Musemwa in their works dealt with these crises and brought independent internal analysis and critical assessment of how they were related to other crises in terms of the time and space in which they occurred and what their individual and collective impact on the citizens of Zimbabwe was like from 1998 to 2009. This article takes over from 2008 to date and it will look at the Zimbabwean economy in areas like manufacturing, the land crisis; media landscape, constitution, judiciary system and humanitarian issues.

\section{Zimbabwean economy (interpretive task)}

Formerly, one of the Africa's sturdiest economies, Zimbabwe was a harbour for development and a beacon for the African Renaissance. In 1978, during the heat of the liberation struggle and international economic sanctions under the colonial administration of Ian Smith, USD 1 was equivalent to ZWD 0.67. In 1983, USD 1 was equivalent to ZWD 1 (Crisis in Zimbabwe Coalition 2010:13). The economy poorly transitioned in recent years, becoming the world's worst economy (as of October 2008). Zimbabwe has the lowest gross domestic product, which represents real growth rate in an independent country, and is third in total behind the Palestinian territories, which are characterised by wars. The devaluation of the Zimbabwean currency was a major challenge to the economic crunch. The Central Bank devalued the currency twice in 2005, and it continued with that trend, so that on 01 April 2007 the parallel market was asking ZWD 30000 for USD 1. At the end of 2007, it was down to about ZWD 2000000 (https://en.wikipedia.orghttps://en. wikipedia.org; accessed 06 November 2017).

As the economy of the country continues to dwindle, the manufacturing industry has not been spared because of a lack of policy integrity by the government. Inclinations indicate a decline in productivity because of the closure of many companies (Mangundhla \& Mambo 2013):

A July 2013 National Social Security Authority (NSSA) Harare Regional Employer Closures and Registrations report for the period July 2011 to July 2013 shows 711 companies in Harare closed down, rendering 8336 individuals jobless. (p. 2)

The other factor that affected the economy was the land invasions; the wave of farm invasions that began soon after the swearing in of Prime Minister Morgan Tsvangirai on 13 February 2009 was a direct deviation from the principles of the GPA. The first recorded incident of fresh invasions was in Mazowe, where suspected Central Intelligence Organization (CIO) officers and army personnel invaded Mazowe Citrus Estates, taking over a section of the farm (General Agricultural Plantation Workers Union of Zimbabwe [GAPWUZ]; 05 March 2009). In the process, 400 out of more than 2000 farm workers were displaced (GAPWUZ, 05 March 2009).

Apart from the farm invasions, another crisis was seen in media. Democracy is promoted by freedom of the media. The media plays an essential role in a democratic society, as the 'fourth estate' tasked with monitoring the three arms of government, namely the executive, the legislature and the judiciary. The Crisis in Zimbabwe Coalition (2010) quoted the Australian politics.com website, which explained the fourth estate as the notion that 'the media's function is to act not only as a guardian of the public interest but as a watchdog on the activities of government and its agencies'.

The media is the principal means through which citizens and their elected representatives communicate to inform and influence each other (Mughan \& Gunther 2000:23). In democratic societies, the media serves to hold the elite accountable and ensure popular control of the government (Mughan \& Gunther 2000:23). Realising the importance of the media in any given society, it is essential for the government of the day to ensure that both the public and private media are protected from manipulation and aided to achieve their ultimate goal of fostering development and democracy. Looking at this period, it is very important to note that the state-controlled or -owned media continues to bowdlerise issues regarding opposition parties while giving precedence to the ruling party, ZANU-PF.

The judicial system in Zimbabwe was also affected; it is clear that the constitution of Zimbabwe provides for the establishment of a judiciary, which is made up of persons who administer justice: judges, magistrates, lawyers and prosecutors. It is another branch, like the army and the civil service, which is supposed to be totally impartial and hence apolitical. This branch of government interprets the law in the name of the state through the courts (Crisis in Coalition Zimbabwe 2010:40). During the period under review and the past decade there was a democratic deficit in Zimbabwe, and many attacks on the judiciary took various forms including the dismissal or suspension of judges who delivered unpalatable decisions, for instance, Justice Blackie and Justice Gubbay (Harare Morning Herald, 04 February 2013:4). 
The humanitarian situation in Zimbabwe was very sad during this period. The economic and political crisis as clearly elaborated earlier on led to a complete collapse in Zimbabwe's service delivery system in 2008. The period before the consummation of the GPA witnessed the closure of more than 12 major referral government hospitals, the spread of the cholera pandemic and the closure of schools. The country's road networks became dilapidated while food shortages were the order of the day. The lives of millions of Zimbabweans were under realistic threat as they faced serious food and water shortages, a breakdown in the health delivery system, proven by the closing of hospitals and the spread of the cholera epidemic (Kasambala 2008:2).

\section{Summary of the Zimbabwean crisis (the normative task)}

Osmer's third task is critical at this point as one tries to understand what ought to be going on in Zimbabwe. The Zimbabwean crises described above were a confluence of several factors such as institutional and constitutional collapse; economic meltdown; endemic corruption; breakdown in the rule of law; gross human rights violations; failure of the ZANU-PF party to transform itself into a national and civilian political party and an inherited colonial state into a democratic one, as well as the failure of liberal democracy.

Given the situation described above it is clear that the Zimbabwean economy has not been able to provide all the people in the country with jobs in the past two decades. This has instigated the increasing terror and apprehension, which has led to profound spiritual consciousness as people appeal to the divine because of the socio-economic and sociopolitical despondency. The hunt for jobs and fear of awful poverty has forced many people to turn to God for divine mediation, direction and provision. It is from this background that this article differs from the crop of prophets and apostles that exists in Zimbabwe today. One example is Johannes Ndanga, the leader of the Apostolic Christian Council of Zimbabwe, who vowed that the 93-year-old Mugabe would die in power (Bulawayo24news.com, 05 November 2017). Ndanga has been in support of Mugabe for a long time and at one time he said that Mugabe was anointed by God (Harare Morning Herald, 04 February 2013):

People might trouble themselves by trying to unseat President Mugabe but let them know that President Mugabe was anointed by God to rule this country and it is only God who can remove him. (p. 4)

In this contemporary context of poverty and political turmoil, there are very few or no prophets or pastors who stand and challenge the status quo. Many preachers are preaching about prosperity, healing and deliverance. In this situation of socio-political and socio-economic crisis the church and its preachers face a great challenge. As disciples of Jesus we are obliged to side with the poor (Pieterse 2013:4). For Pieterse, Jesus calls us to identify with the poor as he did and care for them. Furthermore, he teaches us that he is also present today in the need of the poor, and in caring for them we care for Jesus himself (Mt 25:31-46). Therefore, the first condition for prophetic preaching in such a situation is solidarity with the poor. One has to side with them and experience their life situation existentially (Pieterse 2004:85-87).

\section{An image of prophetic preaching}

McMickle (2006:5) said that prophetic preaching transfers the focal point of the worshippers from what is happening to them as a local church to what is happening to us as a society. Prophetic preaching then asks the question, 'What is the responsibility or the correct response of our congregation, our association and our denomination to the events that are occurring within our society and throughout the world?' In this description of prophetic preaching, McMickle is defining prophetic preaching as it seeks to communicate God's word to people in their context. This is the view of Pieterse when he developed his homiletical theory, which regarded preaching as situational and topical (Pieterse 2013:4). For Pieterse, it is impossible to ignore the poor in a country and merely preach about faith as a private, spiritual affair. Preachers approach the biblical text from their own context (Pieterse 2004:80-82).

A good picture of prophetic preaching points out those false gods of comfort and of a lack of understanding and acceptance in the face of evil that can so easily replace the true God of scripture, who calls true believers to the active pursuit of impartiality and righteousness for every member of society. It was in the same way that the prophets preached truth to the authorities, attacking the crowned heads and the ruling elite for placing more confidence in militia and coalitions than they did in the God who had brought them into that land. The prophets would speak prophetically in challenging the people of Israel, who held the belief that God would never desert them no matter how far the state drifted from the covenant it had predictably established with God long ago.

Pieterse (2001:88), describing prophetic preaching, employed the method of Gadamer and Ricoeur's hermeneutics to reach the zenith of the hermeneutic process, which is the notion of application. For Pieterse, prophetic preaching is approaching the biblical text with a view to interpret it as preaching in a context of poverty. It should be done from the perspective of the poor and therefore in terms of their need for justice and righteousness (Pieterse 2001:88). This view of prophetic preaching resonates well with De Gruchy (1991:19), who used the Kairos Document framework to define South African prophetic theology as a socially critical and world transformative theology that explicitly relates the message of the Bible to the social and political context within which it is being done and proclaimed in preaching (Pieterse 1995:96). For De Gruchy the prophetic preacher should not be afraid to name the injustices, the oppression and the sources of the oppression in the context within which he or she preaches (De Gruchy 1991:19).

The scholars that have been mentioned above push us to concede that to speak for God may be referred to as speaking 
the acerbic frame of what is ethical and what is unethical in the local societies in which they find themselves - to express God's word to allow key actions at catastrophic moments in the life of the church, country and world, to have a preconceived notion in our preaching toward the emancipation of God and the upending of powers and principalities, thus bringing in a period of influence discernible by harmony and equal opportunities and fairness for all (Tisdale 2010:6). Brueggemann (1978) departed from the understanding that prophetic preaching is based on the social, economic and political mayhem in society. In his book The Prophetic Imagination, he reminded people that there are other issues that are greater than we might think at stake. When the textual worldview and our own cultural worldviews collide, Brueggemann maintained, a complete change of acuity and awareness is necessary by those who would attend to the scriptures. In his definition of prophetic preaching he said: 'The task of prophetic ministry is to nurture, nourish, and evoke a consciousness and perception alternative to the consciousness and perception of the dominant culture around us' (Brueggemann 1978:13).

However, it is very important to note that prophetic preaching as understood by Brueggemann does not primarily address the day-to-day political or social and economic bedlam of society, but the word should address in season and out of season, the prevailing mishap that is lasting and hardwearing, of having our unusual career appointed and cultivated. Brueggemann is calling people to reorient and introspectively look into themselves and see things with the eyes of God as Phineas did in Numbers 25. It says:

The Lord said to Moses, 'Phineas son of Eleazar, the son of Aaron, the priest, has turned my anger away from the Israelites. Since he was as zealous for my honour among them as I am'. (vv. 10 and 11)

Phineas was prophetic in the sense that he had the same mind as God, the mind of wiping out evil in the land. It is in the same vein that Abraham Heschel (1962) stated:

The prophets communicated God's anger over the sins of the covenant community. However, what God intends is not that his anger should be executed, but that it should be annulled by the people's repentance. In the final analysis, it is hope and deliverance, not death and destruction that are the ultimate objectives of prophetic preaching. (p. 225)

Heschel's argument was substantiated by Do-Hwa Huh (2005), in his book A New Understanding of Prophetic Preaching. He described prophetic preaching in three roles, which led him to his own definition of prophetic preaching. The three prophetic roles that Do-Hwa Huh developed are, in essence, encirclement of the past, present and future; for him, the prophets often shattered the expectations of their contemporaries by interpreting the past revelation (covenant), by criticism of the present social injustice and by the new revelation of God's' future (Do-Hwa-Huh 2005:42). These three aspects were developed from a variety of roles that have been ratified by the prophets in society. Efforts to express the critical role theory have intermittently hinged on three categories of their social roles: covenant tradition, social justice and God's future. These classifications allow an important connection between the feature of prophetic presentation and the subject of prophetic speech. In the three classes of social roles, the prophets appeal to the covenant relationship with God, criticise corporate oppression and individual collusion, and energise persons and the community of faith by an uncovering of redemptive possibilities (Do-Hwa-Huh 2005:42). It is from these three roles, which were developed from the 'critical role theory', that Do-Hwa-Huh (2005) modelled his definition of prophetic preaching as:

The homiletical mode of bearing faithful witness both to God's word and to the community in such a way that the community is able to recover its ethical relationship to God, to respond to the critical challenge for social transformation, and to embrace an eschatological vision of God's future. (p. 43)

This definition addresses prophetic preaching as biblical preaching in the biblical tradition. Furthermore, prophetic preaching is a faithful witness to what the preacher has seen and heard, namely faithful community of God's word and preaching, and last, prophetic preaching gives meaning to the past, urgent importance to the present and ultimate significance to the future (Fanner 1942:8).

A careful description of prophetic preaching was given by Tisdale (2010) in her book Prophetic Preaching: A Pastoral Approach. She outlined seven hallmarks of prophetic preaching. This was to curtail the omissions of important aspects of prophetic witness that are by the same token factual and imperative. Although we can say that all preaching is prophetic in general terms, prophetic preaching in a situation where a part of the society or community is experiencing injustice and exclusion is a distinctive type of preaching (Tisdale 2010:4). The hallmarks by Tisdale present significant aspects of prophetic preaching because she tries to include all things that are involved in prophetic witness. Prophetic preaching as defined by Tisdale happens when the preacher has the courage to speak truth to authorities not only in the church but also in the society where people are living; hence it is countercultural.

The prophets in the Bible were not afraid to address the evils of the day. For example, Nathan confronted David (2 Sm 12); Jeremiah challenged Jehoiakim (Jer 22:13ff) and Zedekiah (Jer 34). Samuel confronted Saul (1 Sm 15:10ff), Amos condemned Jeroboam (Am 7:10ff) and John the Baptist rebuked Herod (Mt 14). It is in the same vein that preachers in Zimbabwe should walk in the path of the men of the past who lived a prophetic life and be able to challenge the leaders and the status quo. Tisdale (2010:4) noted that prophetic preaching should focus people's attention on the issues that are broader than how to come to church for worship or to be concerned on doctrinal issues, or places of worship as in the story of Jesus and the Samaritan woman. The prophets in the Bible 
always reminded people to go back to the laws God had given them. It is the more task of prophetic preaching to remind people to turn back to the ways of God rather than to relax and concentrate on praise and worship at the expense of justice and righteousness.

Every preacher should identify the content of our prophetic preaching in contemporary Zimbabwe in the specific context of the congregation. Things that can be addressed are corruption by officials administering state funds, maladministration of state funds and unskilled people in crucial positions in the private sector, who cannot do the job but are there because they are ZANU-PF cadres because the policies by the government to redeploy people to other positions after they are found guilty of corruption or maladministration in a previous government position (Pieterse 2013:6). All these things take away the poor from their rights and leave them with no hope for a better life. Some of the results are a derisory functional education system in state schools and a derisory functional medical system in state hospitals and clinics. An important issue is the breakdown of education in the state school system as described above. Preachers should inform themselves on this issue and conscientise members of the congregation in their sermons (Pieterse 2013:6). The churches must also address the government on a continued basis to request that they do something about the situation. Preachers should take note of the news every day and follow issues and developments that can harm the poor and the citizens of Zimbabwe. However, there is also good news: we can play a positive role in this context of poverty. Preachers can conscientise members of the congregation to participate voluntarily in congregational projects of charity and empowerment of the poor, as mentioned (Pieterse 2012:6).

\section{Homiletical theory for praxis (the pragmatic task)}

The previous topics dealt with Osmer's other practical theological tasks; in this section, the homiletical theory for praxis will be developed. In its development the pragmatic task will be employed as it looks at the four elements of preaching and deals with the question, how might we respond? Long (1989:22) noted the crucial ingredients of preaching, the first of which is the congregation, who will of course be the hearers of the preaching. There is the preacher, who arises from the congregation but now stands to preach in front of the community. There is the sermon; it is an action, a spoken event that the preacher performs in Christ's name. Finally, there is the presence of Christ, which is the Holy Spirit. These elements are closely related to each other to form an act of preaching that possesses an inner dynamic; these parts are arranged into an active system (Long 1989:23).

Looking at the preacher, preaching not only requires pastors or preachers to have facility in exegeting and interpreting biblical texts; it also requires of them the ability to 'exegete' the various congregational contexts within which preaching takes place and to speak a word that is both fitting and transformative for a particular place and time (Tisdale 2008:75). A good preacher should have the ability to tap into the universals of human experience that transcend space and time. Pieterse described the preacher in the context of prophetic ministry; for him the prophetic preacher, as part and parcel of the church of the poor, must have a communal and pastoral approach. Markey (1991:9) noted that preaching is first of all a communal activity. The preacher shares the life and praxis of the community of faith. His or her task is to name the experience of the community.

The second element of preaching is congregation. Long (2001:108) noted that it takes a caring and discerning pastor, one who has a healthy relationship with the congregation and a keen and theologically rich understanding of worship, to firmly lead a church to a new and vital place in worship that the members do not yet comprehend and where they would not otherwise be ready to go. Long was of the opinion that for change to occur, a healthy relationship between the pastor and congregation is necessary. Nhiwatiwa (2012:30) underscored that the nature and scope of the message depends on the understanding of a given congregation. Each congregation within the Christian faith has its stages and development patterns. For him, there are likes and dislikes, fears and doubts, strengths and weaknesses that in the end influence the extent and depth of the preached message. Tisdale (2008) was of the same opinion when he said:

I encourage preachers to approach the study of a new congregation much as an ethnographer might study an unknown culture: namely, by attending to the various signs and symbols of its corporate life. (p. 83)

Nhiwatiwa advocated for a holistic approach to the message, one that addresses the whole person, both physically and spiritually. It is the aim of this article to go with Nhiwatiwa's holistic approach and Pieterse, who advocated for the gospel that addresses the whole being of a person. Inasmuch as Africans find solace in momentary spiritual uplifting through the message, preachers must not settle only for these episodic spiritual flights (Nhiwatiwa 2012:31). It is also noted by Wepener (2015:129) in his Boiling Point that there is nothing wrong in experiencing emotions in worship; the problem comes when such experiences become the purpose of the message. He further says that it is extremely important that people be given the opportunity to express their emotions, in a physically embodied way, as part of their expression of faith - an-a aspect that is found in neo-Pentecostal prophets, where the message is centred on one aspect, which is the physical aspect, for instance, material well-being, physical healing and other issues that benefit people physically.

Apart from the congregation, there is the sermon. A sermon should focus on the family and society as a whole, focusing on the pressing existential issues of life. Thompson (2008:61) noted that to preach the word of God is to interpret texts through which God speaks, to offer good news to the community and to invite the listeners to participate in God's 
story. O.P. Cameron, in his book Why Preach, also commented by saying, 'preaching exists in the church to be a life-saving presence that reaches out to those in peril and that rescues them from their despair, their demise' (Cameron 2009:41). Nhiwatiwa (2012:32) is of the opinion that the message preached in Zimbabwean churches also often aims at improving personal morality. Preachers may gain ground when they realise that the sins against which they warn their people should be viewed in light of the prevailing socioeconomic and socio-political situation.

Preachers in Zimbabwe should address the economic crisis that people are experiencing; it is public knowledge that the majority of the population is now surviving on vending, and there has always been a need to provide requisite infrastructure to ensure that vendors carry out their business without violating city by-laws. Vending in Zimbabwe has become common as a result of the deepening economic crisis, reflected in the high unemployment rate. The Harare Morning Newday (14 October 2017:1) reported that President Mugabe ordered the police to clear out vendors in the Central Business District (CBD). This makes their arrest over those days sad. It is almost like their fight for survival has been criminalised. The challenge of the government is that it always has a knack of putting the cart before the horse. A government that knows what it is doing would start by ensuring the availability of proper, adequate and serviced places from which the vendors can carry out their business. It is prudent to avail such spaces in strategic areas within the CBD. While this is happening a message of hope is needed, a prophetic message that addresses the socio-economic ills of the day.

Nhiwatiwa (2012:48) described the role of the Holy Spirit in preaching in an African setup. He noted that the spirit can indwell an individual, and Africans in Zimbabwe and elsewhere believe that a spirit has power to possess an individual for a specific task or purpose. The vocabulary of being possessed by the Holy Spirit has been freely borrowed from this African background and has gained entry into the African church. Nhiwatiwa employed two common words that are used in Shona to describe the process of being possessed, kugarwa and Kusvikirwa ${ }^{3}$ (Nhiwatiwa 2012:46). It is from this background that congregations in Zimbabwe often talk about the preacher being possessed by the Holy Spirit during the delivery of the sermon.

\footnotetext{
3 Kugarwa and Kusvikirwa are Shona terms that mean 'to be possessed', taken from Nhiwatiwa (2012). The author is fully aware that the word 'possessed' is also used Nhiwatiwa (2012). The author is fully aware that the word 'possessed' is also used
in African culture when one is possessed by an evil spirit. When this word is used in in African culture when one is possessed by an evil spirit. When this word is used in
this article the author is referring to Shona congregations, which freely borrowed it from their African background, and it has now gained entry into the African Church. For Nhiwatiwa, the possession usually occurs during animated sermons in which the preacher is engrossed both physically and spiritually. The process is important in the Shona church, as highlighted by the reformers. Martin Bucer (1491-1551) would put it in his Pneumatology of Preaching, 'It is the Spirit who speaks through the minister and who makes the preaching effective and fruitful' (Stephens 1970:138). For Bucer, it is not the work of the preacher but the preacher is possessed, 'under the guidance of the indwelling Spirit of God'. John Calvin is quoted by Parker, saying, 'The Holy Spirit illumines the human mind so that the gospel may be understood. 'The Holy Spirit illumines the human mind so that the gospel may be understood. However, it is through the word that the Spirit [witnesses] to the [word]' (Parke 1947:45). Often, there has been depth of content related in a way meaningful to the lives of the hearers. Possession by the Holy Spirit can take place during a sermon that rings with the truth of the gospel and begs to be heard by more people than those in attendance. Nhiwatiwa noted that this background of the spiritual world helps the African preacher to view the Holy Spirit not only as a church doctrine for theological reflection but as a concrete element to be made use of in preaching.
}

One of the challenges of preaching is having the ability to discern the truth and speak it. Cameron (2009:77) noted that we receive life from the indwelling Spirit and the Word contains in itself the power to save ... it is not only truth; it is power. It not only teaches; it is at work in us. It not only shows us models to imitate; it causes us to act. The Bible (Jn 16:13) tells us that the Holy Spirit guides us into the truth. Preachers in Zimbabwe should be possessed by the Holy Spirit to speak the word of God boldly as the early preachers did, like Peter and Paul, who spoke the word boldly in front of the rulers and religious leaders. They fulfilled the words of Paul in 2 Timothy 1:7, which says, 'For God did not give us a spirit of timidity but a spirit of power and love and self-control'.

Paul's letter to the Galatians (5:18-21) makes a comparison of the works of the spirit and those of the flesh. Contentment can be referred to as a work of the Spirit and greediness as the work of the flesh. However, it is of great importance to look at the gospel of contentment as an act of the Holy Spirit.

Mark L. Y. Chan remarked that 'it will undoubtedly show that human greed played no small part in bringing the world's financial system to the brink of total collapse' (Chan 2009:97). Gregory the Great considered greed as one of the seven deadly sins in his guide for monastic orders. Even the former archbishop of Canterbury, Rowan Williams, argued that 'the root of our current credit crunch is human greed' (Gledhill 2008). What is greediness? Chan defines 'greediness' as 'an inordinate desire or an excessive and insatiable longing to possess money, goods, power, position, and prestige' (Chan 2009:97). Contentment is the opposite of greediness. Does contentment mean accepting mediocrity? Chan (2009) further argues that:

[...] contentment is not the relinquishing of the natural drive that we have to be successful. Scripture commends the healthy ambition to work hard to provide for one's family and help those who are less fortunate (2 Thess 3: 10; 1 Tim 5:8; and Eph 4:28). (p. 102)

So, how does one draw a distinction between contentment and the natural drive for success? Do human beings have the same level of needs and contentment? Chan suggests that 'contentment begins, first of all, with knowing God and knowing who we are in him. Christians can be content because they have God, in whom they find ultimate satisfaction' (Chan 2009:103). Therefore, knowing God means trusting in his goodness in any situation. And be led by the Holy Spirit because one of the works of the flesh is greed as compared to the works of the spirit. 'Contentment therefore, is rooted in a theology of God's love and providential care' (Chan 2009:103). God does not fail to supply all our needs, but what he does not do is to supply all our greed. The gospel of contentment therefore, exhorts us to abandon greediness and accepts God's providence at a given time. Zimbabwe is in a socio-economic and socio-political crisis because there are people in leadership who are greedy - and preachers in Zimbabwe are called to be prophetic and address these social ills in the community. 


\section{Conclusion}

The socio-political and socio-economic crisis has been discussed and in this article it was proven without reasonable doubt that Zimbabwe is indeed in a crisis and preachers are called to be prophetic, as Desmond Tutu was during the South African apartheid. In light of this the research concluded by developing a homiletical theory based on the four elements of preaching - preacher, sermon, congregation and the Holy Spirit. It was discussed that preachers in Zimbabwe are supposed to be seen as prophets in the sense that Pieterse sees them, where one preaches addressing the socio-economic and socio-political bedlam of the people. As servants who are humble as they preach the word, as fathers who love their congregations - these images depict the ways in which the preacher has been described in homiletics. It is important for the preacher to have some clear understanding of the metaphors and images that influence one's preaching of contemporary life, in the framework of God's story. It was also observed that in the African context, especially in Zimbabwe, where people are living with unpredictable and ever-changing socio-economic and socio-political crisis, the gospel message should emphasise pastoral care and compassion. Preachers in Zimbabwe should be guided by the Holy Spirit in order to become prophetic, where the gospel of contentment should be spread, which advocates for the eradication of greediness, encouraging the participation of all people and the inclusion of women and children.

\section{Acknowledgements Competing interests}

The authors declare that they had no financial or personal relationships that may have improperly influenced them in writing this article.

\section{Authors' contributions}

This article is based on the $\mathrm{PhD}$ research of V.F.F and C.W. acted as supervisor.

\section{References}

Brueggemann, W., 1978, The prophetic imagination, Fortress Publishing, Augsburg

Cameron, P.J., (O.P). 2009, Why preach: Encountering Christ in God's Word, Ignatius Press, San Francisco, CA.

Chan, L.Y.M., 2009, 'When more is still less: Greed, idolatry, and contentment', Church \& Society in Asia Today 12(2), 97-106.

Chiumbu, S. \& Musemwa, M., 2012, Crisis! What crisis? The multiple dimensions of the Zimbabwean crisis, Human Sciences Research Council, Cape Town.

Coltart, D., 2016, The struggle continues, 50 years of Tyranny in Zimbabwe, Jacana Media, Sunnyside, WA.

Crisis in Zimbabwe Coalition, A Time to Act, 2010, Can apples be reaped from a thorn tree? Critique of the Inclusive Government of Zimbabwe, viewed 05 June 2017 from https://www.insightonconflict.org/conflicts/zimbabwe/peacebuildingfrom https://www.insightonconflict.org/

De Gruchy, J., 1991, Liberating reformed theology. A South African contribution to an ecumenical debate, David Phillip Publishers, Cape Town.

Do-Hwa-Huh, 2005, 'A new understanding of prophetic preaching', Journal of Evangel 23(2), 39
Fanner, H.H., 1942, The servants of the word, Fortress Press, Philadelphia, PA.

Gledhill, R., 2008, 'Rowan Williams Says, "Human greed to blame for financial crisis"' The Times, viewed 10 July 2017, from http://www.timeonline.co.uk/tol/ comment/faith/article4950733.ece

Hammer, A., MacGregor, J. \& Landau, L., 2010, 'Introduction: Displacing Zimbabwe: Crisis and construction in Southern Africa', Journal of Southern African Studies 36(2), 263-283. https://doi.org/10.1080/03057070.2010.485779

Heschel, A.J., 1962, The Prophets (I and II), Harper \& Row, New York.

Jones, J.L., 2010, "Nothing is straight in Zimbabwe": The rise of the Kukiya-kiya economy 2000-2008', Journal of Southern African Studies 36(2), 285-299. https:// doi.org/10.1080/03057070.2010.485784

Kasambala, T., 2008, Political Poison sickening Zimbabwe, Business Day (South Africa) viewed from https://www.hrw.org/news/2008/12/12/political-poison-sickeningzimbabwe

Long, T.G., 1989, The witness of preaching, Louisville, John Knox Press, KY.

Long, T.G., 2001, Beyond the worship wars. Building vital and faithful worship, Alban Institute, Hemdon, VA.

Mangundhla T. \& Mambo E., 2013, 700 Harare Firms to Close. viewed 12 November 2017 from http://www.mikecampbellfoundation.com/page/

Markey, J.J., 1991, 'The contribution of Edward Schillebeeckx to a theology of preaching', Homiletic XVI (2), 7-10.

McMickle, M.A., 2006, Where have all the prophets gone? Reclaiming prophetic preaching in America, Pilgrim Press, Cleveland, $\mathrm{OH}$.

'MDC Challenges 60 house of Assembly results', Harare Morning Daily News, 16 April, 2008, p. 1.

Mugabe Orders Harare Clean-up', Harare Morning Newsday, 2017, p. 1.

Mughan, A. \& Gunther, R., 2000, Democracy and media: A comparative perspective, Cambridge Press, Cambridge.

Musoni, F., 2010, 'Operation Murambatsvina and the politics of street vendors in Zimbabwe', Journal of Southern African Studies 36(2), 301-317. https://doi.org/ 10.1080/03057070.2010.485786

Nhiwatiwa, E.K., 2012, Preaching in the African context: How we preach? African Series, Discipleship Resource International, Nashville, TN.

Osmer, R.R., 2008, Practical theology: An introduction, William B. Eerdmans, Cambridge.

Parker, T.H.L., 1947, The oracles of God: An introduction to the preaching of John Calvin, Lutterworth Press, London.

Pieterse, H.J.C., 1995, Desmond Tutu's message: A qualitative analysis, J.H. KOK Publishing House, Deutscher Studien Verlag.

Pieterse, H.J.C. (ed.), 2001, Desmond Tutu's message: A qualitative analysis, Brill, Leiden.

Pieterse, H.J.C., 2004, Preaching in a context of poverty, University of South Africa, Pretoria.

Pieterse, H.J.C., 2012, 'A ground theory approach to the analysis of sermons on poverty: Congregational projects as social capital', Verbum at Ecclesia 33(1), 689. https://doi.org/10.4102/ve.v33i1.689

Pieterse, H.J.C., 2013, 'Prophetic preaching in the contemporary context of South Africa', Die Skriflig/In Luce Verbi 47(1), Art. \#114, 6 pages. https://doi.org/10.4102/ ids.v47i1.114

Plantation Workers Union of Zimbabwe (GAPWUZ) report, 2009, 100 Days into the inclusive government: A compendium of reflections from Civil Society Organisations, 05 March 2009.

Raftopoulos, B., 2009a, 'What prospects for Zimbabwe's GNU?', Amandla 7(AprilMay), 28.

Raftopoulos, B., 2009b, 'The crisis in Zimbabwe, 1998-2008', in B. Raftopoulos \& A. Mlambo (eds.), Becoming Zimbabwe: A history from the pre-colonial period to 2008, pp. 190-220, Weaver Press and Jacana Media, Harare and Johannesburg.

Southern African Development Community (SADC), 2008, Election Observer Mission: Preliminary Statement, 27 June 2008.

Stephens, W.P., 1970, The Holy Spirit in Martin Bucer's theology, Cambridge University Press, Cambridge.

'The state of Justice in Zimbabwe', Harare Morning Herald, 2013, p. 4

Tisdale, L.T., 2008, 'Exegeting the congregation', in T.G. Long \&\& L.T. Tisdale (eds.), Teaching preaching as a Christian practice: $A$ new approach to homiletical pedagogy, pp. 75-89, Westminster John Knox Press, Louisville, KYKY.

Tisdale, L.T., 2010, Prophetic preaching: A pastoral approach, Westminster John Knox Press, Louisville, KY.

Thompson, J.W., 2008, 'Interpreting texts for preaching', in T.G. Long \& L.T. Tisdale (eds.), Teaching preaching as a Christian practice: A new approach to homiletical pedagogy, pp. 61-74, Westminster John Knox Press, Louisville, KYKY

Wepener, C.J., 2015, Boiling point: Reflections on anger, A faithful reaction of a disillusioned nation, Biblecor, Wellington.

'Zim heads for run-off', Harare Morning Herald, 03 May, 2008, p. 2. 